\title{
Specific strength training of the flick in Field Hockey through over-weighted balls
}

\author{
F. J. Vizcaya Pérez \\ M. Fernández del Olmo \\ R. Martín Acero
}

https://doi.org/10.5628/rpcd.05.01.40

\author{
Universidade da Coruña \\ Ciencias da Actividade Física e o Deporte (I.N.E.F.) \\ Espanha
}

\begin{abstract}
The purpose of this study was to discover the effect of the specific strength training, using over - weighted balls, on the start speed of the ball, and to verify that the increase is higher when technique and strength training are combined. A specific strength training cycle was carried out for four weeks using different resistance devices (standard, $+5 \%,+10 \%,+15 \%$ and $+20 \%$ ), with two subjects who belong to the Spanish elite. On the other hand, the technical execution of each shooting was analysed by a qualitative observation of the technique with the aim of verifying the effects of this type of strength training on the subjects' technical execution. The results of the study showed an increase in the start speed of the ball up to a highest of $7.41 \%$ (female player), and $21.96 \%$ (male player), and an improvement in the perception of the technical execution after the training cycle, which proved the efficacy of the training carried out.
\end{abstract}

Key Words: specific strength, resistance devices, performance, evaluation of the technique, team sports.

\section{RESUMO}

Treino específico da força do "flick" no Hóquei em Campo com utilização de bolas de peso superior ao regulamentar.

O objectivo deste estudo foi conhecer o efeito de um programa de treino específico de força, utilizando bolas de peso superior ao regulamentar, na velocidade de saída da bola e verificar que o incremento é mais elevado quando o treino da técnica e da força são desenvolvidos de forma combinada. Um ciclo específico de treino de força, utilizando sobrecargas (standard, $+5 \%,+10 \%,+15 \%$ and $+20 \%$ ), foi aplicado durante quatro semanas em dois atletas de elite espanhois. Por outro lado, a execução técnica de cada remate foi analisada através de procedimentos de observação qualitativa da técnica, com o objectivo de verificar os efeitos deste tipo de treino da força no desempenho técnico dos sujeitos. Os resultados do estudo mostraram um incremento na velocidade de saída da bola até um máximo de $7.41 \%$ na jogadora do sexo feminino e de $21.96 \%$ no jogador do sexo masculino, e uma melhoria na percepção da execução técnica após o ciclo de treino, o que provou a eficácia do programa de treino.

Palavras-chave: força específica, equipamentos lastrados, performance, avaliação da técnica, jogos desportivos colectivos. 


\section{INTRODUCTION}

In this research are studied the effects caused by balls of different resistance devices (RD) on the specific strength training of the flick in two elite field hockey players from Spain. This technique could be used in the penalty - corner, a very important move because of the optimum chance to score. In the Olympic Games in Atlanta 1996, 38.1\% (men's class) and $37.8 \%$ (women's class) of goals were scored through a penalty-corner. In the same competition, $8.4 \%$ of the penalty-corner shot by men used this technique and $24.2 \%$ of the shootings was scored. The percentage of the penalty-corner shot by women through a flick decreased $(4.4 \%)$ as well as the goals scored through this technique (12.8\%) (11).

Different RD were used to avoid the establishment of an inflexible stereotype, and to overcome the velocity plateau. The training with balls of different RD (standard, $+5 \%,+10 \%,+15 \%$ and $+20 \%$ ), done by the penalty-corner strikers, and the methods used are shown, analysing the benefits obtained after the training cycle. For this research a previous study, with a sample of 25 Spanish elite field hockey players, was considered in order to estimate the changes in the start speed of the different RD, and to give direction to the specific strength training of the flick with balls of different RD.

\section{BASIS OF SPECIFIC STRENGTH TRAINING THROUGH RESISTANCE DEVICES}

Harre and Lotz (7) indicated the necessity of using the specific movement of competition, with variations of the RD, so that the power and the technical training are sincronized. Schmidtbleicher (10) states that the reach and direction of the movement of training must be as similar as possible to the movement of competition, by way of gaining the highest transfer of training between both movements.

According to González Badillo and Gorostiaga (6), the goal of specific training exercises with $\mathrm{RD}$ is to improve the ability of applying the maximal strength to the specific movement of competition in as little time as possible.

In this study the training through over-weighted balls (with RD higher than the standard ball) is proposed to activate more motor units, recruit more muscle fibers and get a specific morphological, biochemical and physiological adaptation (7).
In order to do this sort of training, the RD to overcome would be always between the limits which let us maintain the external and internal structure of the throwing motion $(8,9,14)$. Training with an excessive RD will not develop specific technique and strength, because it will use unspecific muscle groups (8) and promote dyscoordination (7). The RDs which are employed in the development of the strength could be over- or under-weighted compared with the standard ball. The over-weighted balls decrease acceleration, since they extend the muscular contractions (7), but they develop speed (2). About throwing, Carnevalli (2) suggests that strength is a constituent element of speed. Therefore training with over-weighted implements increases the velocity of throwing whereas training with under-weighted implements is useful to maintain a high speed of throwing when the player is tired, but not to develop the velocity.

On the contrary, Watkinson (14) states that using higher RD will build a specific strength of throwing whereas using lower RD develops speed. González Badillo and Gorostiaga (6) indicate that a specific power could be developed with a slightly lower speed, but with a higher component of specific strength than in competition, in order to increase the velocity of the specific sport movement. Schmidtbleicher (10) completes the Carnevalli's idea suggesting that if it is required to train the fastest motor units - those which develop strength - it will be necessary to do this with high training loads, since only with those loads can be guaranteed the maximum voluntary contraction. Furthermore it would be executed as quickly and as well as possible with these high training loads.

Another perspective to deal with this question is to supply the training with slightly lighter RD than the standard. DeRenne et al. (4) consider that this way of training probably does not increase muscular force at low speed of contraction, but it may improve the muscular strength at high speeds due to the modification of the recruitment pattern of motor units in the central nervous system and increase the throwing velocity.

The RD that have been used in this study were increased in $5 \%, 10 \%, 15 \%$ and $20 \%$, without exceeding the $25-30 \%$ that Kuznetsov (8) indicates to maintain the external and internal structure of the shooting motion. 
In this sort of specific strength training it is necessary to change the weight of the RD in order not to establish an inflexible stereotype within the use of each RD (8). Carnevalli (3) states that the advantages of changing the weight of the RD are: (i) It overcomes the velocity plateau and it prevents its establishment; (ii) It develops the specific muscle groups, according to the guidelines of the technique, since there is a process of learning and adaptation to each implement, if it respects the structure of the specific movement.

As García Manso et al. (5) remarked, there are some studies in which the results show an improvement in the speed of an acyclical movement, such as the punch in karate after the training with over-weighted mittens, or throwing in baseball after training with over-weighted balls.

The number of repetitions is related to the goal of avoiding decrease in the power because of fatigue. So, the training would consist of short sets of ten repetitions at the most (7).

The time of recovering after each set will be three minutes $(7,10)$. This is enough time for the recovery of the nervous system and, in this way, shooting at top speed as quickly as possible (10). Thus the velocity in each repetition is close to the maximum needed in competition (6).

Vizcaya et al. (13), after making a descriptive study with 25 players (males and females) of the Spanish elite to estimate the changes in the start speed of balls of different RD, suggest these groups of RD for the specific training of the strength for the flick in hockey: (i) standard; (ii) a loss of speed smaller than $5 \%$ (RD $+5 \%$ and $+10 \%$ in females; $+5 \%$ in males); and (iii) a loss of speed greater than $5 \%$ ( $\mathrm{RD}+15 \%$ and $20 \%$ in females; and $+10 \%,+15$ $\%$ and $+20 \%$ in males).

To train specialist players, they propose to individualize the RD and test the start speed of each group of balls at the beginning and at the end of each cycle of training (shooting each ball five times).

\section{METHODS}

\section{Subjects}

The subjects of this study were being trained in the Training Center in Madrid: A) Woman, player of the Women's Honour Division (S.P.V. 51) and B) Man, player of Men's First League (Club de Campo). The woman was 29 years old, played in the National Team and won the Gold Medal in the Olympic Games in Barcelona 1992, whereas the man was 17 years old and played in the National Team under 18. Both of them were penalty - corner strikers.

\section{Materials}

The materials used for doing this study were: Official sticks for Fieldhockey; five (5) Fieldhockey balls: 160 g. (standard), 168 g. (+5\%), 176 g. (+ $10 \%), 184$ g. $(+15 \%)$ and 192 g. $(+20 \%)$; Precise scales (Sartorius BP 310 P); Camcorders (2) Sony CCD V 200 (8 mm); Slides, marking pen, set square, triangle, calculator, tape measure and observation table; Video recorder and monitor.

Lead pellets were introduced to ballast the balls used in the study, and their weights were tested with a high precision scale. Finally each ball were sealed with silicone. Before and after each test, the balls were weighed to establish that they had the same weight.

To analyse the start speed of the ball, Aguados'method (1) was used, setting two camcordes with $1 / 1000$ second shutters at right angles and at a distance of 10 meters from the ball and at a height of 1.40 meters high. Each throwing was viewed on a screen, on which was marked the position of the ball just when it had no contact with the stick, and the position of the ball in the next shot, by way of calculating the distance that the ball had covered. This distance was multiplied by a factor of scale which had been calculated before through a reference. The shooting angle of the ball for both camcorders was also estimated. It was found to be a time of 0.04 seconds between shots.

\section{Testing procedures}

A test of the specific strength of flick was done before (T1) and at the end of the training procedures (T2). These testing procedures were suggested by Martin Acero (12) to select overloads for training and consisted of: (i) five strikes thrown with each ball (two minutes of recovery) beginning with the lighter balls ( $5 \times 5$ ); (ii) these shootings were evaluated by the subject and an external observer, through an observation table, which was filled after each throwing ( 1 to 5 scale, from worst to best 
shooting). Performer and observer did not know the evaluations of the other one until the test was over; (iii) the average of the five throwings with each five balls was analysed.

\section{Training procedures}

A four-week training program was developed to increase the specific power, based on variations of the RD, with the aim of improving the start speed of the ball with flick penalty-corner strikers. During that period the players were trained twice a week with the different weights (RD), as already described. They were training with their teams to improve the other technical and tactical parameters of the game.

The weekly number of shootings and the use of the different RD were varied right through the training cycle. In this way, the first week (300 shootings) was distinguished because of having more shootings with the most over-weighted balls, followed by the intermediate group and, finally, the standard RD. The order of this distribution was changed through the weeks, so that in the second session of the third week there were not any shootings with balls of the most over-weight group, and in the last week there were only 150 shootings with the standard RD (Figure 1). Likewise, the weekly distribution of the shootings was about $50 \%$ with each RD of each group.

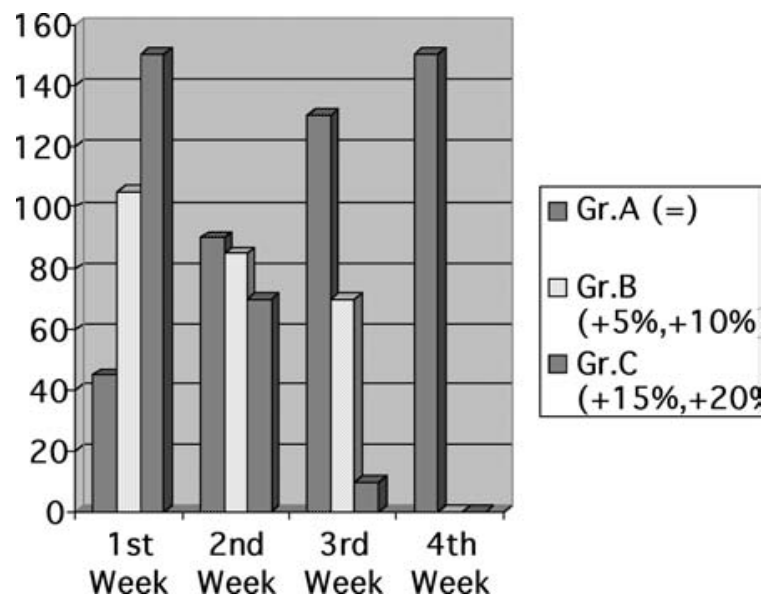

Figure 1. Number of throwings concerning the four-week training cycle.
To determine the RD to use in this study and to evaluate the improvements caused by the specific strength training, a test was done before and after the training cycle, with the testing procedures already described.

\section{Statistical analysis}

These are single subject design (n1) with a female player (F) and a male player (M) who are penaltycorner strikers. Both case studies were analysed with the following aims: (i) To determine the possible statistically significant difference among the mean of the start speed of the ball, before and after the training cycle, all shootings (5) which were done with each type of ball (5) were analysed, through nonparametric statistical tests: the Mann-Whitney $U$ test and the Kolmogorov-Smirnov test.; (ii) To evaluate the improvements in the speed, without disorders in the technique, the most valued shooting by the performer (F or $\mathrm{M}$ ) and the expert observer (Ex) was selected and analysed through: the MannWhitney $U$ test and the Kolmogorov-Smirnov test; (iii) To determine the possible statistical significant difference in the evaluation of the technical performance, both internal (F or M) and external (Ex), before and after the training cycle, all valuations of the five shootings with each type of ball (5) were analysed, through nonparametric statistical tests: the Mann-Whitney $U$ test, the Kolmogorov-Smirnov test, the Wilcoxon matched-pairs signed-ranks test and the Kruskal-Wallis test.

\section{RESULTS}

The results of the mean speed of the shootings with the standard RD, which were done by the penaltycorner female striker, in prior (T1) and posttest (T2), are shown in Table 1.

Table 1. The mean speed of the standard ball $[R D=]$ of the female $(F]$ player's shootings (5) before (T1) and after the training cycle (T2).

\begin{tabular}{|l|l|l|l|l|l|l|}
\hline $\mathrm{F}$ & \multicolumn{2}{|l|}{$\begin{array}{l}\text { Start speed } \\
\text { of the ball in } \\
\text { T1 }\end{array}$} & $\begin{array}{l}\text { Start speed of } \\
\text { the ball in T2 }\end{array}$ & \multicolumn{2}{l|}{ Gain Score T1 - T2 } \\
\hline $\begin{array}{l}\text { Resistance } \\
\text { Devices }\end{array}$ & $\begin{array}{l}\text { Mean } \\
\left(\mathrm{m} \cdot \mathrm{s} \Gamma^{1}\right)\end{array}$ & SD & $\begin{array}{l}\text { Mean } \\
\left(\mathrm{m} \cdot \mathrm{s} \Gamma^{1}\right)\end{array}$ & SD & $\begin{array}{l}\text { Gain } \\
\left(\mathrm{m} \cdot \mathrm{s} \Gamma^{1}\right)\end{array}$ & Increase(\%) \\
\hline $\begin{array}{l}\text { Standard } \\
\text { (=) }\end{array}$ & 18.47 & .12 & 18.69 & 1.09 & 0.23 & 1.25 \\
\hline
\end{tabular}


An increase of $1.25 \%$ in the start speed of the standard ball was appreciated after the strength training cycle. However, there was no statistically significant difference in the mean of the five shootings between $\mathrm{T} 1$ and $\mathrm{T} 2$.

In the case of the female player $(\mathrm{F})$ a greater increase $(+7.41 \%)$ after the training cycle was observed, when the most valued shooting by the expert observer and the female player was chosen and analysed (Table 2), that is, the shooting which in their opinion was the best, in an external and internal way.

Table 2. Start speed of the ball in the most valued shooting by the female player (F) and the expert observer ( $E x$ ] before (T1) and after the training cycle (T2).

\begin{tabular}{|l|l|l|l|l|}
\hline $\begin{array}{l}\text { Resistance } \\
\text { Devices }\end{array}$ & $\begin{array}{l}\text { Start } \\
\text { speed of } \\
\text { the ball in } \\
\mathrm{T} 1(\mathrm{~m} \cdot \\
\left.\mathrm{s} \Gamma^{1}\right)\end{array}$ & $\begin{array}{l}\text { Start } \\
\text { speed of } \\
\text { the ball in } \\
\mathrm{T} 2[\mathrm{~m} \cdot \\
\left.\mathrm{s} \Gamma^{1}\right)\end{array}$ & $\begin{array}{l}\text { Gain }(\mathrm{m} \cdot \\
\left.\mathrm{s} \Gamma^{1}\right]\end{array}$ & $\begin{array}{l}\text { Increase } \\
{[\%]}\end{array}$ \\
\hline $\begin{array}{l}\text { Standard } \\
{[=]}\end{array}$ & 18.62 & 20.00 & 1.38 & 7.41 \\
\hline
\end{tabular}

Concerning the male player $(\mathrm{M})$, the results of the mean speed of the shootings and the speed of the most valued shooting, by the expert observer and the male player, with the standard $\mathrm{RD}$ are shown in Tables 3 and 4.

Table 3. The mean speed of the standard ball (RD) of the male (M) player's shootings (5) before (T1) and after the training cycle (T2).

\begin{tabular}{|l|l|l|l|l|l|l|}
\hline M & \multicolumn{2}{|l|}{$\begin{array}{l}\text { Start speed } \\
\text { of the ball in } \\
\text { T1 }\end{array}$} & \multicolumn{2}{l|}{$\begin{array}{l}\text { Start speed } \\
\text { of the ball in } \\
\text { T2 }\end{array}$} & \multicolumn{2}{l|}{ Gain Score T1 - T2 } \\
\hline $\begin{array}{l}\text { Resistance } \\
\text { Devices }\end{array}$ & $\begin{array}{l}\text { Mean SD } \\
\left(\mathrm{m} \cdot \mathrm{s} \Gamma^{1}\right]\end{array}$ & $\begin{array}{l}\text { Mean } \\
(\mathrm{m} \cdot \\
\left.\mathrm{s} \Gamma^{1}\right]\end{array}$ & SD & $\begin{array}{l}\text { Gain } \\
(\mathrm{m} \cdot \\
\left.\mathrm{s} \Gamma^{1}\right)\end{array}$ & Increase[\%] \\
\hline $\begin{array}{l}\text { Standard } \\
{[=]}\end{array}$ & 18.08 & 4.26 & 22.05 & .90 & $3.9 ?$ & 21.96 \\
\hline
\end{tabular}

Table 4. Start speed of the ball in the most valued shooting by the male player (M) and the expert observer ( $E x$ ] before (T1) and after the training cycle (T2).

\begin{tabular}{|l|l|l|l|l|}
\hline $\begin{array}{l}\text { Resistance } \\
\text { Devices }\end{array}$ & $\begin{array}{l}\text { Start } \\
\text { speed of } \\
\text { the ball in } \\
T 1\left(\mathrm{~m} \cdot \mathrm{s} \Gamma^{1}\right)\end{array}$ & $\begin{array}{l}\text { Start } \\
\text { speed of } \\
\text { the ball in } \\
\mathrm{T} 2\left(\mathrm{~m} \cdot \mathrm{s} \Gamma^{1}\right)\end{array}$ & $\begin{array}{l}\text { Gain }(\mathrm{m} \cdot \\
\left.\mathrm{s} \Gamma^{1}\right)\end{array}$ & $\begin{array}{l}\text { Increase } \\
{[\%]}\end{array}$ \\
\hline $\begin{array}{l}\text { Standard } \\
{[=\mathrm{J}}\end{array}$ & 22.17 & 22.62 & 0.45 & 2.03 \\
\hline
\end{tabular}

In the case of the male player (M), it is remarkable that the increase in the mean speed of the five shootings (Table 3 ) is greater than the speed of the most valued shooting by the expert observer and the male player (Table 4) $(21.96 \%$ versus $2.03 \%)$. There were also statistically significant differences in the analysis of the mean speed of the five standard RD shootings (Mann-Whitney $U$ test, $\mathrm{p}=0.007$ ). On the other hand, the results of the technical valuation are shown in Tables 5 (female) and 6 (male). In this regard, the possible statistical significant difference between the technical valuation of the expert observer and the valuation of the two players in the performance of the shootings with the different RD were analysed, without finding significant differences between them, except for the case of the standard ball in $\mathrm{T} 1$, in which was found statistically significant difference in the technical valuation of the female player's shootings $(p=0.034$, Wilcoxon matched-pairs signed-ranks test).

Table 5. Mean valuation ( 5 shootings) internal (female player) and external (expert observer) of the performance of the technique.

\begin{tabular}{|c|c|c|c|c|c|}
\hline \multicolumn{6}{|c|}{ Technical Valuation } \\
\hline \multirow{2}{*}{$\begin{array}{l}\text { Resistance } \\
\text { Devices }\end{array}$} & \multirow{2}{*}{$\begin{array}{l}\text { Type of } \\
\text { Valuation }\end{array}$} & \multicolumn{2}{|c|}{ Valuation in T1 } & \multicolumn{2}{|c|}{ Valuation in $\mathrm{T} 2$} \\
\hline & & Mean & SD & Mean & SD \\
\hline \multirow{2}{*}{$\begin{array}{l}\text { Standard } \\
{[=]}\end{array}$} & $\begin{array}{l}\text { External } \\
\text { [Ex] }\end{array}$ & 4.60 & .55 & 4.80 & .45 \\
\hline & $\begin{array}{l}\text { Internal } \\
\text { (F) }\end{array}$ & 2.40 & .89 & 4.60 & .55 \\
\hline \multirow{2}{*}{$+5 \%$} & $\begin{array}{l}\text { External } \\
\text { [Ex] }\end{array}$ & 4.00 & 1.73 & 4.00 & 1.41 \\
\hline & $\begin{array}{l}\text { Internal } \\
\text { (F) }\end{array}$ & 3.60 & $1.6 ?$ & 3.40 & 1.82 \\
\hline \multirow{2}{*}{$+10 \%$} & $\begin{array}{l}\text { External } \\
{[\text { Ex }]}\end{array}$ & 4.20 & 1.10 & 3.40 & 2.19 \\
\hline & $\begin{array}{l}\text { Internal } \\
(\mathrm{F})\end{array}$ & 3.40 & .55 & 3.00 & 1.58 \\
\hline \multirow{2}{*}{$+15 \%$} & $\begin{array}{l}\text { External } \\
{[\text { Ex] }}\end{array}$ & 4.40 & .55 & 4.60 & .55 \\
\hline & $\begin{array}{l}\text { Internal } \\
{[F]}\end{array}$ & 4.20 & .45 & 4.20 & .84 \\
\hline \multirow{2}{*}{$+20 \%$} & $\begin{array}{l}\text { External } \\
{[\text { Ex] }}\end{array}$ & 4.20 & 1.79 & 4.60 & .55 \\
\hline & $\begin{array}{l}\text { Internal } \\
(\mathrm{F})\end{array}$ & 3.80 & 1.64 & 5.00 & .00 \\
\hline
\end{tabular}


Table 6. Mean valuation (5 shootings) internal (male player) and external (expert observer) of the performance of the technique.

\begin{tabular}{|c|c|c|c|c|c|}
\hline \multicolumn{6}{|l|}{ Technical Valuation } \\
\hline \multirow{2}{*}{ Resistance Devices } & \multirow{2}{*}{ Type of Valuation } & \multicolumn{2}{|c|}{ Valuation in $\mathrm{T} 1$} & \multicolumn{2}{|c|}{ Valuation in $\mathrm{T} 2$} \\
\hline & & Mean & SD & Mean & SD. \\
\hline \multirow{2}{*}{ Standard [=] } & External (Ex) & 3.00 & 2.00 & 4.60 & .55 \\
\hline & Internal (M) & 3.00 & 2.00 & 4.40 & .89 \\
\hline \multirow{2}{*}{$+5 \%$} & External (Ex) & 4.20 & 1.79 & 4.80 & .45 \\
\hline & Internal (M] & 3.60 & 1.52 & 4.40 & .55 \\
\hline \multirow{2}{*}{$+10 \%$} & External (Ex) & 4.60 & .55 & 4.00 & 1.73 \\
\hline & Internal (M) & 4.40 & .89 & 3.80 & 1.79 \\
\hline \multirow{2}{*}{$+15 \%$} & External (Ex] & 3.00 & 1.87 & 4.20 & 1.79 \\
\hline & Internal (M) & 3.20 & 2.05 & 4.00 & 1.73 \\
\hline \multirow{2}{*}{$+20 \%$} & External (Ex) & 4.00 & 1.73 & 3.80 & 1.79 \\
\hline & Internal (M) & 4.20 & 1.30 & 3.80 & 1.30 \\
\hline
\end{tabular}

The possible statistically significant difference in the technical valuation was analysed with the aim of verifying a possible improvement in the performance of the technique, and significant difference was found with the standard ball in the internal valuation of the female player ( $p=0.007$, Mann-Whitney $U$ test). Statistical difference was not appreciated in the rest of the valuations. However, analysing the addition of the technical val- uations (internal + external), an improvement in the self-efficacy perception was observable, since both subjects improved the addition of their valuations, in such a way that in the case of the female player (F) the addition increased from 194 to 208, whereas in the case of the male player (M) the addition of valuations increased from 186 to 209 , after the training cycle (Tables 7 and 8).

Table 7. Addition of the internal $[F]$ and external $[\varepsilon x]$ valuations for the female player's shootings [F] with the different resistance devices, before and after the training cycle.

\begin{tabular}{|l|l|l|l|l|l|l|}
\hline & \multicolumn{4}{|l|}{ Before the training cycle } & \multicolumn{2}{l|}{ After the training cycle } \\
\hline Resistance Devices & Internal (F) & External [Ex] & $\begin{array}{l}\text { Internal }+ \\
\text { External }\end{array}$ & Internal $[F]$ & External [Ex] & $\begin{array}{l}\text { Internal + } \\
\text { External }\end{array}$ \\
\hline Standard [=) & 12 & 23 & 35 & 23 & 24 & 47 \\
\hline$+5 \%$ & 18 & 20 & 38 & 17 & 20 & 37 \\
\hline$+10 \%$ & 17 & 21 & 38 & 15 & 17 & 32 \\
\hline$+15 \%$ & 21 & 22 & 43 & 21 & 23 & 44 \\
\hline$+20 \%$ & 19 & 21 & 40 & 25 & 23 & 48 \\
\hline TOTAL & 87 & 107 & 194 & 101 & 107 & 208 \\
\hline
\end{tabular}

Table 8. Addition of the internal (M) and external $[\varepsilon x$ ] valuations for the male player's shootings (M) with the different resistance devices, before and after the training cycle.

\begin{tabular}{|l|l|l|l|l|l|l|}
\hline & \multicolumn{4}{|l|}{ Before the training cycle } & \multicolumn{2}{l|}{ After the training cycle } \\
\hline Resistance Devices & Internal (M) & External [Ex] & $\begin{array}{l}\text { Internal + } \\
\text { External }\end{array}$ & Internal (M) & External [Ex] & $\begin{array}{l}\text { Internal+ } \\
\text { External }\end{array}$ \\
\hline Standard [=] & 15 & 15 & 30 & 22 & 23 & 45 \\
\hline$+5 \%$ & 18 & 21 & 39 & 22 & 24 & 46 \\
\hline$+10 \%$ & 22 & 23 & 45 & 19 & 20 & 39 \\
\hline$+15 \%$ & 16 & 15 & 31 & 20 & 21 & 41 \\
\hline$+20 \%$ & 21 & 20 & 41 & 19 & 19 & 38 \\
\hline TOTAL & 92 & 94 & 186 & 102 & 107 & 209 \\
\hline
\end{tabular}


Analysing the possible significant difference in the technical valuation, depending on the RD which has been used, to discover if an increase in the RD would affect the subjects' performance perception ( $\mathrm{M}$ and $\mathrm{F}$ ), there was no statistically significant difference in the internal and external valuation.

\section{DISCUSSION}

a) In order to determine the possible statistically significant difference among the average of the start speed of the ball and the most valued shooting by the player (F or M) and the external observer (Ex), before and after the training cycle.

In the statistical analysis of the results obtained through the training with penalty-corner strikers, special attention to the standard RD was paid, because of being used in the competition and being the most important goal in the improvement in the specific strength of these players.

However, so as to design the training program, the start speed of different RD was analysed with the aim of gathering the balls of training: individualised prescription of the RD (9).

As regards the selected shootings to the analysis of the start speed of the ball, it is suggested to select those which technical performances (internal and external) were the most valued, or considering the mean of shootings whose valuations were over 3 , so as to exclude the shootings with mistakes in performance, which cause a loss of precision.

As far as the analysis of the start speed of the standard $\mathrm{RD}$ is concerned, an improvement after the training cycle was observed in the female player $(\mathrm{F})$. Although there was a higher improvement, taking the best technical valuation into consideration, both in the view of the player and the expert observer, instead of the average speed of the five shootings, since the increase goes from $1.25 \%$ to $7.41 \%$. In this analysis, in spite of the increase after the training cycle with different RD, statistically significant difference was not found in the shootings with the standard ball. An improvement after the training cycle was also appreciated in the male player (M), but this was higher when the mean speed of the five shootings was considered instead of the most valued shooting (internal and external), since it increased a $21.96 \%$ and a $2.03 \%$, respectively.
This difference in the improvement that the training caused in the male player (M), could be due to the inclusion in the $\mathrm{T} 1$ analysis of several shootings with technical mistakes which could have generated a low speed: $13.27 \mathrm{~m} \cdot \mathrm{s} \Gamma^{1}$. Moreover, in the shootings which were analysed in T2, whose technical valuations were over 3 , there was one of $23.35 \mathrm{~m} \cdot \mathrm{s} \Gamma^{1}$ (against $22.62 \mathrm{~m} \cdot \mathrm{s} \Gamma^{1}$ ) which would increase the improvement by $5.32 \%$, instead of $2.03 \%$.

In the case of the male player $(\mathrm{M})$, there was statistically significant difference in the shootings with the standard RD (Mann-Whitney $U$ test $\mathrm{p}=0.047$ ). The different performances of the male $(\mathrm{M})$ and the female $(\mathrm{F})$ player showed the necessity of individualising the RD and testing the start speed in each group of balls with the penalty-corner strikers, such as Vizcaya et al (13) suggested.

b) In order to determine the possible statistical significant difference in the technical valuation, both internal and external, before and after the training cycle. The results which were obtained in this study, in relation with the technical valuation, on the part of the players and the expert observer, revealed that there was no statistically significant difference between both valuations (except in the case of the female player $(\mathrm{F})$ and her shootings with the standard ball from $\mathrm{T} 1$ to $\mathrm{T} 2$ ).

This coherence in their valuations, joined to the fact that statistically significant difference in the technical valuations was not found, according to the RD used and as the RD was increased, showed that the $\mathrm{RD}$ of this study allowed keeping the internal and external structure of the movement which the subject perceived. Moreover, the specific strength and the technique of flick shooting were being trained at the same time.

Significant difference was found in the internal valuation of the female player $(\mathrm{F})$ in the shootings with the standard RD from T1 to T2 ( $\mathrm{p}=0.007$ MannWhitney $U$ test and $\mathrm{p}=0.013$ Kolmogorov-Smirnov test). This would be attributed to an increase in the self-efficacy perception of the player, after the training cycle, since her valuation went from a mean of 2.40 (T1) to 4.60 (T2).

The addition of the valuations (internal + external) reached 194 points in T1, which was increased to 208 
in T2. It may be asserted that an improvement in the technical performance existed, in spite of the strength training with balls of mixed RD, and between the limits which probably allowed not altering the internal and external structure of the movement.

As regards the male player $(\mathrm{M})$, there was no statistically significant difference, in the external and internal valuation, after the training cycle. However, comparing the addition of the valuations (internal + external), an increase in the technical valuation could be observed, from 186 points to 209 in T2, which would suggest a perception of the improvement in the performance after the training cycle.

\section{CONCLUSIONS}

After the training cycle for specific strength with two penalty-corner strikers, an increase in the start speed of the standard ball resulted, which proved the efficacy of the training.

According to the results, the resistance devices (RD) used in the study were suitable and they were kept between the limits which probably do not alter the perception of the internal and external structure of the movement.

The training of the specific strength through balls of RD different from the standard was effective in improving the technical performance, since in the training done, the shooting technique and the strength development were combined, and both seemed to improve as the increase in the start speed of the ball and in the valuation of the technical performance showed.

The difference in the achieved improvement of the female and male player, both in the start speed of the ball and in the technical valuation (internal and external), demonstrated the necessity of individualising the loads of the specific strength training, with the aim of being able to adapt them to the characteristics of the players and that the improvement of the start speed of the ball and the performance of the technique could be increased.

\section{Acknowledgements}

To the fieldhockey players Sonia Barrio and Jaime Mendez who colaborated in this study. To the coaches Marc Lammers, Ma Angeles Rodriguez and Jose Antonio Gil, from the National Team and the Training Centre in Madrid, and Jose Manuel Brasa, from Club de Campo.

The abstract of this research was published by World Hockey, n. 38.

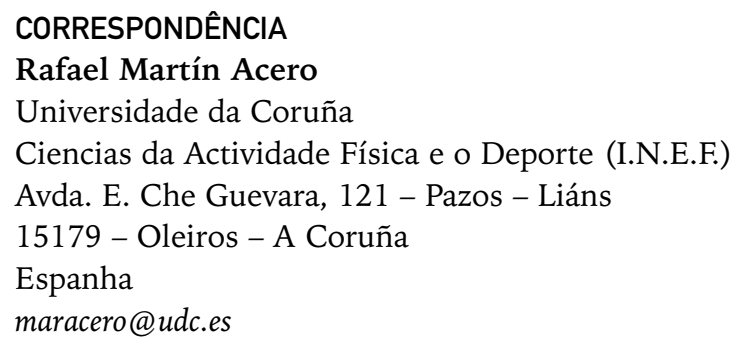




\section{REFERENCES}

1. Aguado X, Izquierdo M (1995). 16 prácticas de biomecánica. León: Universidad de León.

2. Carnevalli R (1985). Periodización y principios técnicos del entrenamiento de los lanzadores. Lanzamientos II. Cuadernos de Atletismo 17: 51-67.

3. Carnevalli R (1985). Aspectos de la preparación de los lanzadores de alto nivel. Atletismo de alto rendimiento. Cuadernos de atletismo 18: 83-92.

4. DeRenne C, Ho K, Blitzblau A (1990). Effects of Weighted Implement Training on Throwing Velocity. Journal of Applied Sport Science Research. 4(1):16-19.

5. García Manso J, Navarro JM, Ruiz JA, Martín Acero R (1998). La velocidad. Madrid: Gymnos.

6. González Badillo JJ, Gorostiaga E (1995). Fundamentos del entrenamiento de la fuerza. Aplicación al alto rendimiento deportivo. Barcelona: Inde.

7. Harre D, Lotz I (1988). Entrenamiento de la fuerza rápida. Revista de Entrenamiento Deportivo 2 (3): 42-49.

8. Kuznetsov V (1984). Metodología del entrenamiento de la fuerza para deportistas de alto nivel. Buenos Aires: Stadium.

9. Martín Acero R (1993). Programación del entrenamiento de la velocidad de desplazamiento. Madrid: Centro Olímpico de Estudios Superiores.

10. Pensikov V, Denissove E (1994). Ejercicios especiales para los lanzadores de disco. Stadium 166: 3-9.

11. Schmidtbleicher D (1988). Resultados y metodología de investigación del entrenamiento de fuerza. Entrenamiento de la fuerza rápida. Cuadernos de Atletismo 23: 5-74.

12. The Atlanta Committee for the Olympic Games (1996). Official Results Atlanta Hockey. Atlanta: Author.

13. Vizcaya FJ, Martín Acero R (1998) Adestramento da Forza Especial do push en Hockey. VI Congreso de Educación Física $e$ Ciencias do Deporte dos Países de Língua Portuguesa. VII Congreso Galego de Educación Física e Deporte. A Coruña, Julio 1998.

14. Vizcaya FJ, Fernández M, Martín Acero R (1999). Determinación de sobrecargas para el entrenamiento de la fuerza especial del flick en hockey (y un caso de entrenamiento del push). Infocoes 4(1): 117-129.

15. Watkinson JA (1997). Strength, Speed, Power Approach to Improving Throwing Velocity in Baseball. Strength and Conditioning 19 (5): 42-47. 